\title{
PENGARUH MODEL PEMBELAJARAN CTL (CONTEXTUAL TEACHING \& LEARNING) TERHADAP HASIL BELAJAR MATA PELAJARAN INSTALASI PENERANGAN LISTRIK SISWA KELAS XI SMK DINAMIKA PEMBANGUNAN 1 JAKARTA
}

\author{
${ }^{1}$ Alfridus Tena, ${ }^{2}$ Soeprijanto, ${ }^{3}$ Drs. Irzan Zakir \\ 1,2,3 Pendidikan Teknik Elektro, Fakultas Teknik, Universitas Negeri Jakarta \\ 1,2,3 Email : alfridustena234@gmail.com; soeprijanto@unj.ac.id; irzan.zakir@unj.ac.id
}

\begin{abstract}
This research was conducted with the grade XI students of TITL, SMK Dinamika Pembangunan I Jakarta, on the subject of the Electrical Lighting Installation (IPL). The researcher precieved the poor results from the students who have not achieved the standard completion of studies (SKB) during and after they underwent and internalized learning activities in the process of their study. The objective of this research is to realize the difference between the results of study on Electrical Lighting Installation using Contextual Teaching and Learning method and the result of the study using the Convensional method in grade XI TITL, SMK Dinamika Pembangunan 1 Jakarta. The hippotetical test using $t$-test resulted in $t$-counted $=2.32$ at the significance of $\alpha=0.05$ and the 45 level of tolerance which resulted in $t$-table $=2.00$. Therefore, the value is within the area of acceptance of $H_{1}$ and rejection of $H_{0}$. This shows that the average result of study using the Contextual Teaching and Learning model is better compared to the result of study using the conventional model.
\end{abstract}

Keywords : Contextual Teaching and Learning (CTL), Learning Results of Electrical Lighting Installation Techniques.

\begin{abstract}
Abstrak
Penelitian ini dilakukan di kelas XI TITL SMK Dinamika Pembangunan 1 Jakarta pada mata pelajaran Instalasi Penerangan Listrik (IPL). Peneliti melihat rendahnya hasil belajar siswa yang belum mencapai Standar Ketuntasan Belajar (SKB) dalam menerima dan meresapi kegiatan belajar disaat proses pembelajaran berlangsung maupun sesudahnya. Tujuan yang ingin dicapai dalam penelitian ini adalah untuk mengetahui perbedaan hasil belajar mata pelajaran Instalasi Penerangan Listrik siswa yang dibelajarkan dengan model contextual teaching and learning dengan siswa yang dibelajarkan dengan model konvensional XI TITL di SMK Dinamika Pembangunan 1 Jakarta. Pengujian hipotesis menggunakan uji-t diperoleh thitung $=2,32$ pada taraf signifikansi $\alpha=0.05$ dan derajat kebebasan 45 diperoleh ttabel $=2,00$, maka nilai thitung berada di daerah penerimaan $\mathrm{H}_{1}$ diterima dan $\mathrm{H}_{0}$ ditolak. Hal ini menunjukan bahwa rata-rata hasil belajar dengan menggunakan model pembelajaran Contextual Teaching and Learning lebih tinggi dibandingkan dengan hasil belajar yang menggunkan model pembelajaran konvensional.
\end{abstract}

Kata Kunci: Contextual Teaching and Learning (CTL), Hasil Belajar Teknik Instalasi Penerangan Listrik.

\section{PENDAHULUAN}

Kemajuan kehidupan suatu bangsa sangat ditentukan oleh pendidikan. Pendidikan yang tertata dengan baik dapat menciptakan generasi yang berkualitas, cerdas, adaptif, dan bermoral. Untuk mencapai tujuan di atas, Departemen Pendidikan Nasional telah melakukan berbagai upaya untuk meningkatkan mutu pendidikan, antara lain dengan mengadakan berbagai pelatihan dan peningkatan kualitas guru, penyempurnaan kurikulum, pengadaaan buku, alat pelajaran, dan masih banyak lagi.

Peningkatan pendidikan dapat menghasilkan lulusan yang sesuai dengan tuntutan kebutuhan berbasis potensi Sumber Daya Manusia (SDM) Indonesia. Peningkatan kualitas Sumber Daya
Manusia (SDM) melalui pendidikan akan menghasilkan SDM yang mampu bersaing secara sehat dalam ketatnya kompetisi Dunia Usaha/Dunia Industri (DU/DI). Sehingga sangat diharapkan adanya lembaga yang menghasilkan Sumber Daya Manusia yang berkompeten dibidangnya seperti Sekolah Menengah Kejuruan (SMK).

Sekolah merupakan salah satu lembaga pendidikan formal yang akan menghasilkan lulusan yang nantinya diharapkan mempunyai lulusan yang dibutuhkan baik di dunia usaha/dunia industri (DU/DI). Sekolah yang mampu menghasilkan Sumber Daya Manusia (SDM) yang terampil dan berkualitas lebih ditujukan kepada SMK (Sekolah Menengah Kejuruan). Hal ini dilatarbelakangi oleh Peraturan 
Pemerintah (PP) No. 29 Tahun 1990, Pasal 3 ayat 2, yaitu, "Menyiapkan peserta didik untuk memasuki lapangan kerja serta mengembangkan sikap profesional".

Instalasi penerangan merupakan pelajaran produktif yang terdapat di jurusan teknik instalasi tenaga listrik di SMK Dinamika Pembangunan 1 Jakarta. Terdapat teori dan praktikum di dalam mata pelajaran instalasi penerangan. Teori di dalam mata pelajaran instalasi penerangan ini mengacu pada rangkaian listrik yang didalamnya terdapat banyak komponen untuk menentukan jawaban serta konsep ilmu kelistrikan yang harus dipahami.

Tenaga pendidik yang profesional dapat membuka wawasan berpikir yang beragam dari siswa, mereka dapat mempelajari berbagai konsep dan mampu mengkaitkannya dengan kehidupan nyata, sehingga dapat membuka berbagai pintu kesempatan selama hidupnya. Pengajaran dan Pembelajaran Kontekstual (Contextual Teaching Learning) merupakan konsep belajar yang membantu guru mangaitkan antara materi yang diajarkan dengan situasi dunia nyata siswa agar mendorong siswa membuat hubungan antara pengetahuan yang dimilikinya dengan penerapannya dalam kehidupan mereka sebagai anggota keluarga dan masyarakat. Pada pengajaran berbasis CTL, tugas guru adalah membantu siswa mencapai tujuannya. Guru lebih banyak berurusan dengan strategi daripada memberi informasi. Tugas guru mengelola kelas sebagai sebuah tim yang bekerja sama untuk menemukan sesuatu yang baru bagi anggota kelas (siswa). Depdiknas (2007) dalam Sosialisasi KTSP (Kurikulum Tingkat Satuan Pendidikan) menyebutkan," Pengalaman di negara lain menunjukkan bahwa minat dan prestasi siswa dalam bidang matematika, sains, dan bahasa meningkat secara drastis pada saat :

1. Mereka dibantu untuk membangun keterkaitan antara informasi (pengetahuan) baru dengan pengalaman (pengetahuan lain) yang telah mereka miliki atau mereka kuasai.

2. Mereka diajarkan bagaimana mereka mempelajari konsep, dan bagaimana konsep tersebut dapat dipergunakan di luar kelas.
3. Mereka diperkenankan untuk bekerja secara bersama-sama (cooperative).

Meningkatnya minat dan prestasi siswa tersebut dicapai, karena guru menggunakan suatu pendekatan pembelajaran dan pengajaran kontekstual" (Depdiknas 2006).

Sekolah Menengah Kejuruan Dinamika Pembangunan 1 Jakarta kelas XI terdapat 2 kelas, yang masing-masing kelas berjumlah 30 siswa. Menurut pengamatan di lapangan dan informasi dari guru-guru serta karyawan setempat serta mahasiswa UNJ yang PKM di SMK Dinamika Pembangunan 1 Jakarta dari sekian banyaknya siswa tersebut, masih banyak yang mengalami kesulitan dalam belajar, terlihat dari adanya siswa-siswa yang enggan belajar dan tidak bersemangat dalam menerima pelajaran yang di sampaikan guru pada saat kegiatan belajar di kelas. Siswa pun yang belum aktif dalam mengerjakan soal latihan yang diberikan oleh guru. Sehingga hasil belajar pun menjadi kurang memuaskan karena masih banyak nilai dibawah standart kelulusan, padahal selama ini sudah ada fasilitas-fasilitas sekolah yang diberikan guna menjunjang sarana prasaran demi kelancaran dalam proses pembelajaran. Hal itulah yng menjadi permasalahan peniliti, sehingga peneliti ingin menetahui lebih jauh tentang pengaruh hasil belajar dengan menggunakan metode Pembelajaran Contextual Teaching and Learning (CTL) terhadap hasil belajar yang dicapai oleh siswa.

Setelah ditelaah, CTL belum diterapkan untuk mata pelajaran instalasi penerangan di sekolah. Melalui penelitian ini, mau dijelaskan dan menerapkan model $C T L$ untuk mata pelajaran instalasi penerangan. Dengan melihat fenomena saat ini yang terjadi di sekolah, pembelajaran instalasi penerangan banyak dilakukan dengan memberi konsep tanpa melalui pengolahan potensi yang ada pada diri siswa maupun yang ada di sekitarnya. Pembelajaran CTL membantu siswa mengaitkan pelajaran akademik dengan konteks kehidupan nyata yang siswa hadapi.

\section{METODELOGI PENELITIAN}

Jenis penelitian yang digunakan adalah penelitian kuantitatif, berupa metode quasy 
eksperimental. Pemilihan metode penelitian ini karena sampel diambil secara acak (random sampling) kemudian digunakan satu kelas eksperimen yang akan diberikan perlakuan berupa pembelajaran menggunakan Contextual Teaching \& Learning (CTL) dan satu kelas lainnya sebagai kelas kontrol, tidak diberikan pembelajaran menggunakan CTL. Kelompok kontrol ini tidak sepenuhnya mengontrol variabel-variabel luar yang mempengaruhi eksperimen (Sugiyono, 2012: 77). Metode penelitian quasy eksperimen adalah penelitian yang digunakan untuk mencari pengaruh perlakuan tertentu terhadap yang lain dalam kondisi yang terkendalikan (Sugiyono, 2012: 107).

Populasi merupakan wilayah generalisasi yang terdiri atas objek/subjek yang memiliki kualitas dan karakteristik tertentu yang ditetapkan oleh peneliti untuk dipelajari dan kemudian ditarik kesimpulannya (Sugiyono, 2016: 80). Populasi dalam penelitian ini adalah seluruh siswa kelas XI TITL Dinamika Pembangunan 1 Jakarta yang terbagi menjadi tiga kelas yaitu XI TITL 1 yang berjumlah 36 siswa, XI TITL 2 yang berjumlah 33 siswa, dan kelas XTITL 3 yang berjumlah 35 siswa.

Sampel adalah bagian dari jumlah dan karakteristik yang dimiliki oleh populasi tersebut (Sugiyono, 2016: 81). Sampel yang digunakan dalam penelitian ini terdapat dua kelas dari jumlah tiga kelas di XI TITL SMK Dinamika Pembangun 1 Jakarta. Sampel diambil dengan cara probability sampling yaitu teknik pengambilan sampel yang memberikan peluang yang sama bagi setiap anggota populasi untuk dipilih menjadi anggota sampel. Kedua kelas tersebut dijadikan sampel. Kedua kelas tersebut dipilih secara random.

\section{HASIL PENELITIAN}

Deskripsi data hasil penelitian dimaksudkan untuk memberikan gambaran umum mengenai hasil pengolahan data yang didapat dari variabel dalam penelitian ini yaitu hasil belajar Instalasi Penerangan Listrik pada siswa SMK kelas XI TITL Dinamika Pembangunan 1 Jakarta dengan model contextual teaching and learning. Data hasil belajar diperoleh melalui instrumen penelitian yang berisi soal Instalasi Penerangan
Listrik. Soal ini terdiri dari tiga kompetensi dasar dengan jumlah item yang digunakan sebanyak 30 soal pertanyaan pilihan ganda. Soal ini diisi oleh 60 siswa kelas XI Teknik Instalasi Tenaga Listrik SMK DP Jakarta. Untuk mendeskripsikan data dalam penelitian ini, maka pada bagian ini akan disajikan deskripsi data dari masing-masing variabel berdasarkan data yang diperoleh di sekolah sebagai berikut:

\section{Hasil Belajar Instalasi Penerangan Listrik Model Contextual Teaching and Learning}

Data hasil belajar Instalasi penenarangan Listrik dengan perlakuan Contextual Teaching and Learning (kelas A) dengan siswa 30 orang menghasilkan nilai rata rata (mean) 82,4 , nilai tengah (median) 84, nilai yang diperoleh siswa paling banyak (modus) 84, varian 127.285, simpangan baku 11,285, nilai terbesar 100 , nilai terkecil 60, interval kelas 6 dan panjang kelas 7 .

Table. 4.1. Frekuensi hasil belajar instalasi penerangan model kontekstual teaching and learning

\begin{tabular}{cccccc}
\hline No & Interval & $\begin{array}{l}\text { Batas } \\
\text { Bawah }\end{array}$ & Fi & Fkum & Fi.Xi^2 \\
\hline 1 & $60-66$ & 59,5 & 4 & 4 & 15876 \\
2 & $67-73$ & 66,5 & 3 & 7 & 14700 \\
3 & $74-80$ & 73,5 & 5 & 12 & 29645 \\
4 & $81-87$ & 80,5 & 6 & 18 & 42336 \\
5 & $88-94$ & 87,5 & 8 & 26 & 66248 \\
6 & $95-101$ & 94,5 & 4 & 30 & 38416 \\
& $\Sigma$ & & & 30 & 207221 \\
& & & & & \\
\hline
\end{tabular}

Untuk mempermudah penafsiran distribusi frekuensi dari tabel maka disajikan grafik histogram sebagai berikut:

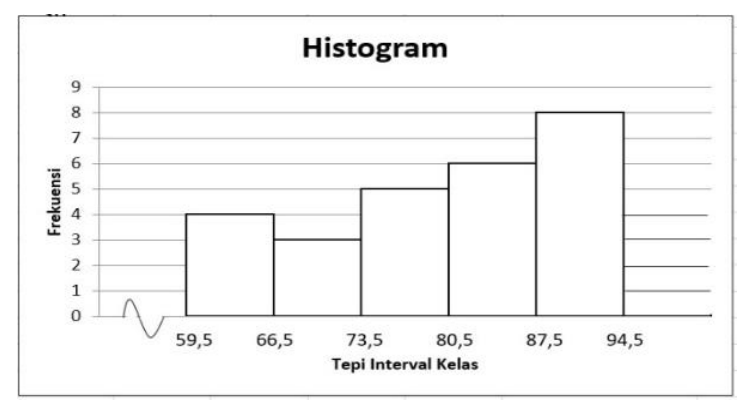

Pada grafik diatas dapat disimpulkan bahwa perolehan nilai terbanyak berada pada interval 
87.5 - 94.5, sementara perolehan nilai terendah berada pada interval $66.5-73.5$.

\section{Hasil Belajar Instalasi Penerangan Listrik Model Konvesional}

Data hasil belajar siswa pada mata pelajaran Instalasi Penerangan Listrik bangunan gedung dengan perlakuan model konvesional dengan membenarkan rangkaian hasil kerja yang ada (kelas B) yaitu, memiliki nilai rata-rata (mean) 75.900, median 76,7, modus 77,06, interval kelas 6 , panjang kelas 8, varian 134.180, dan simpangan baku 11.548 .

Tabel. 4.2 Tabel Frekuensi Hasil Belajar Instalasi Penerangan Listrik Model Konvesional

\begin{tabular}{cccccc}
\hline No & Interval & $\begin{array}{c}\text { Batas } \\
\text { Bawah }\end{array}$ & Fi & Fkum & Fi.Xi^2 $^{\wedge}$ \\
\hline 1 & $50-57$ & 49,5 & 3 & 3 & 8586.75 \\
2 & $58-65$ & 57,5 & 2 & 5 & 7564.5 \\
3 & $66-73$ & 65,6 & 6 & 11 & 28981.5 \\
4 & $74-81$ & 73,5 & 10 & 21 & 60062.5 \\
5 & $82-89$ & 81,5 & 5 & 26 & 36551.25 \\
6 & $90-97$ & 89,5 & 4 & 30 & 34969 \\
& $\Sigma$ & & 30 & & 176715.5
\end{tabular}

Untuk mempermudah penafsiran distribusi frekuensi dari tabel diatas maka disajikan grafik histogram sebagai berikut:

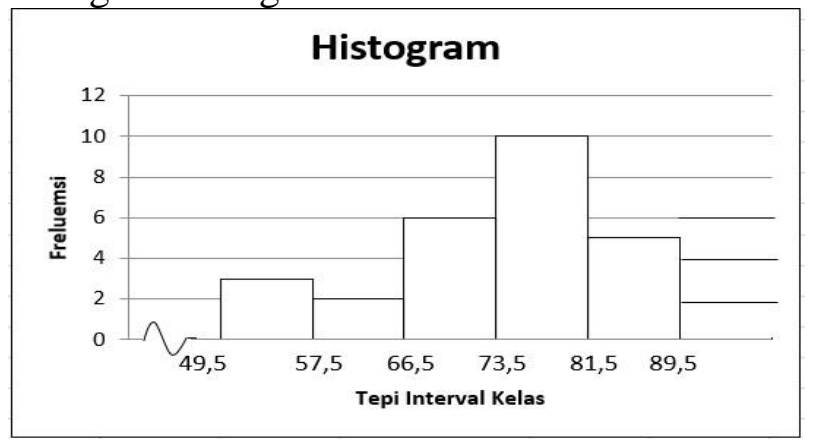

\section{Hasil Pengujian Normalitas Data}

1. Kelompok Eksperimen Kelas A Model Contextual Teaching and Learning

Uji normalitas dilakukan dengan uji liliefors dan hasil pengujian dengan $(\mathrm{n})=30, \alpha=0,05$ model contextual Teaching and Learning pada Instalasi Penerangan Listrik diperoleh $\mathrm{L}_{\text {tabel }}=0,161$ dan $\mathrm{L}_{\text {hitung }}=0,087$, maka sampel berasal dari distribusi normal karena $\mathrm{L}_{\text {hitung }}<\mathrm{L}_{\text {tabel. }}$ Maka dapat disimpulkan bahwa hasil belajar model contextual
Teaching and Learning pada instalasi Penerangan Listrik berdistribusi normal. (terlampir)

2. Kelompok Eksperimen Kelas B Model Konvesional

Uji normalitas dilakukan dengan menggunakan uji Liliefors dan hasil pengujian dengan $(n)=30$, $\alpha=0,05$ model Contextual Teaching and Learning dengan membenarkan rangkaian hasil kerja yang ada diperoleh $\mathrm{L}_{\text {tabel }}=0,161$ dan $\mathrm{L}_{\text {hitung }}=$ 0,0866, maka sampel berasal dari distribusi normal karena $\mathrm{L}_{\text {hitung }}<\mathrm{L}_{\text {tabel. }}$. Maka dapat disimpulkan bahwa hasil belajar model Contextual Teaching and Learning pada instalasi Penerangan Listrik berdistribusi normal.

\section{Hasil Pengujian Homogenitas}

Uji homogenitas atau uji kesamaan kedua kelas (kelas A dan kelas B) dilakukan dengan ujian Fisher. Hasil pengujian diperoleh $F_{\text {hitung }}=1.262$, $\mathrm{F}_{\text {tabel }}=1.84$ pada taraf signifikansi $\alpha=0,05$ dengan derajat kebebasan pembilang 30-1 = 29 dan derajat kebebasan penyebut $30-1=29$. Karena $\mathrm{F}_{\text {hitung }}<\mathrm{F}_{\text {tabel }}$ yaitu $1.262<1,84$ maka dapat disimpulkan $\mathrm{H}_{\mathrm{o}}$ diterima varian populasinya homogen.

\section{Pengujian Hipotesis}

Pengujian hipotesis menggunakan uji-t diperoleh $t_{\text {hitung }}=2,3190$ pada taraf signifikansi $\alpha$ $=0,05$ dan derajat kebebasan 59 diperoleh $t_{\text {tabel }}=$ 2.0021 karena $t_{\text {hitung }} 2,3190>t_{\text {tabel }} 2,0021$, maka nilai thitung berada didaerah penerimaan $\mathrm{H}_{1}$ diterima ( $\mathrm{H}_{0}$ ditolak). Hal ini menunjukkan bahwa rata-rata hasil belajar dengan menggunakan model Contextual Teaching and Learning dengan membenarkan angkaian hasil kerja yang ada lebih tinggi dibandingkan dengan hasil belajar dengan menggunakan model konvesional pada instalasi penerangan listrik.

\section{Pembahasan Hasil Penelitian}

Masalah yang dibahas pada penelitian ini adalah apakah terdapat pengaruh hasil belajar antara siswa yang diajarkan dengan menggunakan model Contextual Teaching and Learning pada instalasi penerangan dengan siswa yang diajarkan dengan model konvesional dengan membenarkan rangkaian hasil kerja yang ada pada mata 
pelajaran Instalasi Penerangan Listrik, berdasarkan penelitian menggunakan uji-t pada sub bab sebelumnya menunjukkan bahwa adanya perbedaan hasil belajar dimana siswa yang diajar menggunakan model Contextual Teaching and Learning dengan membenarkan rangkaian hasil kerja yang ada memiliki nilai rata rata hasil belajar 82.4 sedangkan siswa yang diajar menggunakan model pembelajaran konvesional pada instalasi penerangan memiliki nilai rata rata 75.900 . dengan perhitungan uji-t diperoleh $t_{\text {hitung }}=2,3190$ pada taraf signifikansi $\alpha=0,05$ dan derajat kebebasan 59 diperoleh $t_{\text {tabel }}=2.0021$, maka nilai $\mathrm{t}_{\text {hitung }}$ berada didaerah penerimaan $\mathrm{H}_{1}$ diterima dan $\mathrm{H}_{0}$ ditolak. Hal ini menunjukkan bahwa rata-rata hasil belajar dengan menggunakan model Contextual Teaching and Learning dengan membenarkan rangkaian hasil kerja yang ada lebih tinggi dibandingkan dengan hasil belajar dengan menggunakan model konvesional pada instalasi penerangan listrik.

Dari hasil analisa data yang telah diperoleh, dapat disimpulkan bahwa secara keseluruhan model contextual teaching and learning memberikan pengaruh lebih baik daripada model konvesional. Dengan demikian peningkatan hasil belajar dapat diperoleh dengan menggunakan model contextual teaching and learning.

\section{KESIMPULAN DAN SARAN \\ Kesimpulan}

Berdasarkan hasil uji dan pembahasan pada bab sebelumnya dapat disimpulkan bahwa terdapat perbedaan hasil belajar siswa kelas XI SMK Dinamika Pembangunan 1 Jakarta pada mata pelanajaran Instalasi Penerangan Listrik antara yang menggunakan model contextual teaching and learning dan model konvesional. Siswa yang diajarkan menggunakan model contextual teaching and learning memiliki nilai raa-rata lebih tinggi yakni 82,4 sedangkan siswa yang diajarkan menggunakan model konvesional memiliki nilai rata-rata hasil belajar 72,900. Selain dapat dibuktikan dengan perhitungan ratarata nilai hasil belajar siswa, hal ini juga dapat dilihat dari hasil uji hipotesis. Pengujian hipotesis menggunakan uji-t dimana $\mathrm{H}_{1}$ diterima dengan hasil perhitungan uji hipotesis. Pengujian hipotesis menggunakan uji-t diperoleh thitung $=$ 2,3190 pada taraf signifikansi $\alpha=0,05$ dan derajat kebebasan $59 \mathrm{t}_{\text {tabel }}=2.0021$, maka nilai thitung berada didaerah penerimaan $\mathrm{H}_{1}$ diterima dan $\mathrm{H}_{0}$ ditolak.

\section{Saran}

Berdasarkan hasil penelitian yang diperoleh maka peneliti menyarankan beberapa hal seperti:

1. Hasil penelitian menunjukkan bahwa metode belajar contextual teaching and learning menghasilkan nilai hasil belajar siswa lebih tinggi maka disarankan guru lebih kreatif dalam proses pembelajaran supaya bisa menstimulus keaktifan siswa selama proses belajar

2. Guru hendaknya lebih berani untuk mencoba beberapa metode pembelajaran supaya dapat meningkatkan proses berpikir siswa dan mampu memecahkan masalah, sehingga secara tidak langsung dapat meningkatkan nilai yang diperoleh siswa.

3. Hasil penelitian menunjukkan bahwa hasil belajar siswa yang menggunakan model contextual teaching and learning lebih tinggi sehingga guru dapat menjadikan model pembelajaran ini sebagai referensi untuk digunakan pada kegiatan belajar Instalasi Penerangan Listrik.

\section{DAFTAR PUSTAKA}

Arikunto, Suharsimi. 2012. Dasar-Dasar Evaluasi Pendidikan. Jakarta: Bumi Askara.

Al-Tabany, Trianto. (2014). Mendesain Model

Pembelajaran Inovatif, Progresif, dan Konstekstual. Jakarta: Prenadamedia Group.

Aunurrahman. 2012. Belajar dan Pembelajaran. Bandung: Alfabeta.

Badan Standarisasi Nasional. 2000. Persyaratan Umum Instalasi Listrik 2000 (PUIL 2000). Jakarta: BSN.

Daryanto. 2013. Media Pembelajaran. Bandung: Satu Nusa.

Daryanto. 2013. Strategi dan Tahapan Mengajar Bekal Keterampilan Dasar Bagi Guru. Bandung: CV Yrama Widya. 
Depdiknas. 2004. Kurikulum SMK Edisi 2004. Jakarta: Depdiknas.

Depdiknas. 2007. Model Penilaian SMK. Jakarta: Depdiknas.

Depdiknas. 2007. Sosialisasi KTSP. Jakarta: Depdiknas.

Dewi Setiayastuti. 2009. Meningkatkan Hasil Belajar Melalui Penerapan Model Pembelajaran Kontekstual (Contextual Teaching and Learning) Pada Mata Pelajaran Menata Produk di Kelas XII Penjualan 1 SMK Taman Siswa 1 Jakarta. Skripsi FE: UNJ.

Gulo, W. (2002). Strategi Belajar Mengajar. Jakarta: Grasindo.

Hamiyah Nur dan M. Jauhar. 2014. Strategis Belajar Mengajar di Kelas. Jakarta. Prestasi Pustakaraya.

Hamdayama, Jumanta. 2014. Model dan Metode Pembelajaran kreatif dan Berkarakter. Bogor: Ghalia Indonesia.

Johnson, Elaine B. (2002). Contextual Teaching and Learning: What is is and

why it's here to stay. Bandung: MLC.

Johnson, Elaine B. 2014. Contectual Teaching and Learning. Bandung: Kaifa.

Leksair, Markus Alexander. Peningkatan HasilBelajar Matematika Melalui Model Pembelajaran Contextual Teaching and Learning. Vol. 6 No. 9 Tahun 2017. http://journal.student.uny.ac.id/ojs/index. php/pgsd/article/view/8116 (diakses 29 November 2017)

Neidle, Michael. 1999. Teknologi Instalasi Listrik Edisi III. Jakarta: Erlangga.

Nurhidayah dkk. Penerapan Model Contextual Teaching Learning (CTL) terhadap Hasil Belajar Fisika pada Siswa Kelas XI SMA Handayani Sungguminasa Kabupaten Gowa. Vol 4, No 2 (2016). http://journal.unismuh.ac.id/index.php/jpf

/article/view/307 (diakses pada 29

November 2017)

Pengaruh Model Pembelajaran CTL (Contextual

Teaching and Learning) terhadap Motivasi

dan Hasil Belajar Siswa SMKN 1

Sidoarjo. Jurnal Mahasiswa Unesa.

https://jurnalmahasiswa.unesa.ac.id/

(diakses pada 29 November 2017)

Purwanto. 2011. Evaluasi Hasil Belajar. Yogyakarta: Pustka Pelajar.

Rusman.2012. Model-model pembelajaran. Jakarta: Raja Grafindo Persada.

Rusman. 2014. Model-model Pembelajaran. Depok: PT Rajagrafindo Persada.

Rusmono. 2012. Strategi Pembelajaran dengan Problem Based Learning itu Perlu untuk meningkatkan professionalism Guru./Rusmono. 2012. Jakarta: Ghalia Indonesia.

Satriani, Intan dkk. Contextual Teaching and Learning Approach to Teaching Writing. Vol. 2, No. 1 Tahun 2012.

http://ejournal.upi.edu/index.php/IJAL/art icle/view/70 (diakses 29 pada November 2017

Sikumbang, Rusman 2014. Strategi Pembelajaran dengan Problem Based Learning itu perlu. Bogor: Ghalia Indonesia.

Siregar, Eveline dan Hartini Nara. 2014. Teori belajar dan pembelajaran. Jakarta: Ghalia Indonesia.

Sugiyono. 2016. Metode Penelitian Kuantitatif Kualitatif dan R\&D. Bandung: Alfabeta.

Sudjana, Nana. 1989. Dasar-dasar Proses Belajar Mengajar. Bandung: Sinar Baru Algesindo.

Samaulah, Hazairin. 2002. Teknik Instalasi Tenaga Listrik. Bandung: Unsri

Supardi. 2016. Aplikasi Statistika Dalam Penelitian. Jakarta: Change Publication.

Surapranata, Sumarna. 2004. Analisis, Validitas, Reliabilitas, dan Interpretasi Hasil Tes, Implementasi Kurikulum 2004. Bandung: PT Remaja Rosdakarya 
Suryatmo, F. 1998. Teknik Listrik Instalasi Penerangan. Jakarta: Bineka cipta.

Susanto, Ahmad (2013). Teori Belajar dan Pembelajaran di Sekolah Dasar. Jakarta: Kencana.

Suryatmo, F. 2002. Dasar-Dasar Teknik Listrik. Jakarta: Rineka Cipta

Tim Guru Produktif TITL. (2016). Modul Menganalisis Rangkaian Listrik. Cakung: SMK Dinamika Pembangunan 1 Jakarta.

Tim Guru Produktif TITL. (2016). Panduan Praktek Kelas X TITL. Cakung: SMK Dinamika Pembangunan 1 Jakarta.

Trianto. 2015. Model Pembelajaran Terpadu. Jakarta: Bumi Aksara.

Widianto, Harnoko Satria. 2013. Perbedaan Hasil Belajar Melakukan Pengukuran Besaran Listrik antara yang Menggunakan Model Pembelajaran Espositori dengan Model Pembelajaran Kontekstual (Contextual Teaching and Learning). Studi Pada Siswa Kelas X SMK Negeri 4 Tangerang. Skripsi FT: UNJ. 